\title{
Molecular Changes and Gene Expression of Glutathione Peroxidase in Adrenal Gland during Experimental Fluorosis
}

\author{
A. Shashi* and Neha Sharma \\ Department of Zoology and Environmental Sciences, Punjabi University, \\ Patiala-147002, Punjab, India \\ *Corresponding author
}

Keywords

Adrenal gland, Gene expression, Glutathione peroxidase, RT-PCR, Sodium fluoride.

\section{Article Info}

Accepted:

18 November 2016

Available Online:

10 December 2016

\section{A B S T R A C T}

Fluorosis is known to cause several metabolic and degenerative disorders and has alarming upsurge in the recent years which is a matter of deep concern and need intense research. The gene expression of the anti-oxidant enzyme glutathione peroxidase was studied in adrenal gland of Wistar albino rats treated with sodium fluoride at the dose of $100,200,300 \mathrm{ppm} / \mathrm{kg} \mathrm{b.w}$. orally for 40 days. The levels of DNA, RNA and proteins in adrenal gland were lower and showed negative corelation with fluoride. RT-PCR analysis showed a decrease in glutathione peroxidase gene expression in response to fluoride intoxication, suggesting a role for post translational modification in altering the activities of this enzyme. Western-blot analysis showed that due to oxidative stress protein was expressed at $24-\mathrm{kDa}$ in all fluoride treated groups. Random Amplification of Polymorphic DNA marker were generated via the polymerase chain reaction using shorter primers of an arbitrary sequence. With high concentration of fluoride rapid gel images showed greater variation then at low dose which was due to certain mutation which change the primer binding site.

\section{Introduction}

Endemic fluorosis is now known to be global in scope, occurring on all continents and affecting many millions of people. It is characterized by dental mottling and skeletal manifestations such as crippling deformities, osteoporosis and osteosclerosis. However, in the last decade, interest in its undesirable effects has resurfaced due to the awareness that this element interacts with cellular systems even at low doses.

In recents years, several investigations demonstrated that fluoride can induce oxidative stress and modulate intracellular redox homeostasis, lipid peroxidation and protein carbonyl content, as well as alter gene expression and cause apoptosis. Gene modulated by fluoride include those related to stress response, metabolic enzymes, the cell cycle, cell communicatons and signal transductions (Barbier et al., 2010).

Adrenal gland is multifunctional steriodogenic organ. Adrenal gland have many features which renders from susceptible to toxicological insult including 
free radical generation during steroid biosynthesis (Verma and Rana, 2009). The enzymes of steroid biosynthesis are targets for various toxicants, the effects of endocrine disrupting chemicals on adrenal function have been studied (Hinson and Raven, 2006).

The purpose of this study was to examine molecular aspects of fluoride exposure on cellular processes with respect to physiological and toxicological implications.

\section{Materials and Methods}

\section{Experimental design}

Male and female Wistar albino rats, weighing between 100-150g were housed in polypropylene cages with stainless still grill tops and fed with standard rat pellet diet (Hindustan Lever Limited, India) and water was given ad libitum. The animals were acclimatized for two weeks before starting the experiment. After the acclimatization period, they were randomly divided into eight groups containing six rats in each. The animals of control group received $1 \mathrm{ppm}$ deionized water/kg b.w./day and the remaining groups were given sodium fluoride at the dose of $100,200,300 \mathrm{ppm} / \mathrm{kg}$ b.w. for 40 days. The animals were sacrificed under ether anaesthesia. Aliquots of adrenal samples were kept in RNA later $^{\mathrm{TM}}$ (Ambion, USA) and assayed for the quantitative estimation of DNA, RNA and proteins.

\section{Ethical Aspects}

The experiments were performed under the approval of animal ethical committee of Punjabi University, Patiala, India. (Animal maintenance and Registration No. 107/99/CPCSEA-2013-42).

\section{Isolation of DNA}

DNA isolation protocol was performed by the method of Hoarau et al., (2007).

\section{Total RNA isolation and RT-PCR}

Total RNA isolation and RT-PCR was performed by method described by Strong et al. (1984) and Poinar and Jansson (1986).

\section{Total mRNA extraction}

Total mRNA extraction was done by the method of Chomczynski and Mackey (1995).

\section{cDNA synthesis}

First strand cDNA synthesis was performed by the method given by Berger et al., (1988), Frohmam et al., (1988).

\section{Primer Designing and Selection}

A set of specific forward and reverse primers for the amplification of the cDNA of adrenal gland was selected. The cDNA of tissue synthesized were used as the template for specific primers.

\section{PCR amplification}

PCR program consisted of initial denaturation at $96^{\circ} \mathrm{C}$ for 5 minutes, followed by 45 cycles of denaturation at $94^{\circ} \mathrm{C}$ for 1 minute, annealing at $36^{\circ} \mathrm{C}$ for 90 seconds and extension at $72^{\circ} \mathrm{C}$ for 2 minutes and final extension of 7 minutes at $72^{\circ} \mathrm{C}$ in MWG Biotech Thermo Cycler.

\section{Electrophoresis}

Amplified products were run in $1.8 \%$ agarsoe gel with 100bp ladder and visualized in Gel Documentaion system. 


\section{RAPD (Random Amplification of Polymorphic DNA)}

RAPD was performed by the method of Botstein et al., (1980) and Williams et al., (1990).

Amplification reaction was performed in a $25 \mu \mathrm{l}$ volume mastermix containing $(6.78 \mu \mathrm{l}$ distilled water , and $2.5 \mu \mathrm{l}$ of $10 \mathrm{X}$ buffer, $3 \mathrm{ul}$ of primer each $(30 \mathrm{pM} / \mathrm{ml}), 2.5 \mu l$ stock solution of $\mathrm{MgCl}_{2}(25 \mathrm{mM}), 4 \mu \mathrm{l}$ DNTP $\operatorname{mix}(25 \mathrm{mM}), 0.22 \mu 1$ Taq polymerase enzyme (5units/ $\mu \mathrm{l})$. 3ul of DNA (47ng/ul) was used

\section{Primer used}

Primer 1 : 5'-GATTCACTG C-3'

Primer 2 : 5'-TGTCTGGGT G-3'

Primer $3: 5^{\prime}$-GGTCCCTGA C-3'

\section{Protein isolation and quantification}

Estimation of protein was done by the method of Lowry et al., (1951).

\section{Western blotting for proteins}

Western blotting was performed by the method given by Vinh Pham (2003).

\section{Statistical Analysis}

The data was analyzed using statistical package SPSS version 17 for windows Inc. Chicago, II. Statistical analysis was performed using the Pearson's correlation test. One-way analysis of variance (ANOVA) was used to compare the means. The Tukey-Kramer post-hoc test was applied to identify significance among groups. Multiple pair-wise comparisons among all treatment groups were performed by Bonferroni post-hoc. The value of $p<0.05$ was considered to be statistically significant. Results and Discussion

\section{Quantification estimation of DNA and} RNA

DNA

The level of DNA in the adrenal gland of test rats showed significantly $(\mathrm{F}=96.364, \mathrm{p}<0.001)$ decline after 40 days of fluoride toxicity (Fig. 1). The highest dose group (300 ppm fluoride/kg b.w./day) exhibited decline of $5.08 \%$.

Bonferroni multiple comparison test after ANOVA ( $\mathrm{F}=96.364, \mathrm{p}<0.001)$ showed a significant decrease in the level of DNA in adrenal gland $(95 \% \mathrm{CI}=0.005$ to 0.071 ) with mean difference of 0.021 to 0.055 among fluoride treated groups as well as compared to control.

Pearson's bivariate correlation analysis revealed a significant $(\mathrm{r}=-0.955, \mathrm{p}<0.001)$ negative relationship between levels of fluoride and DNA in adrenal gland of test rat after 40 days of fluoride treatment. Further regression analysis $\left(\mathrm{Y}=1.774-0.127 \mathrm{X}, \mathrm{R}^{2}=\right.$ 0.912 ) showed that as the level of fluoride decreases in adrenal gland of rats, the DNA content also declined (Fig. 2).

\section{RNA}

The level of RNA in adrenal gland of rats treated with sodium fluoride for 40 days was significantly $(\mathrm{F}=641.853, \mathrm{p}<0.001)$ declined. More prominent decrease was registered in highest dose group (300 ppm fluoride/ $\mathrm{kg}$ b.w./day) (Fig. 3).

Bonferroni multiple comparison test after ANOVA ( $\mathrm{F}=641.853, \mathrm{p}<0.001)$ showed a significant decrease in the level of RNA in adrenal gland $(95 \% \mathrm{CI}=0.013$ to 0.115$)$ with 
mean difference of 0.032 to 0.097 among all fluoride treated groups as well as compared to control.

Pearson's bivariate correlation analysis revealed a significant $(\mathrm{r}=-0.972, \mathrm{p}<0.01)$ negative relationship between level of fluoride and RNA in adrenal gland of test rat after 40 days of fluoride treatment. Further regression analysis ( $\mathrm{Y}=2.918-0.366 \mathrm{X}, \mathrm{R}^{2}=$ 0.945) showed that as the level of fluoride increases, the level of RNA was declined (Fig. 4).

\section{RT-PCR}

The adrenal gland mRNA used for cDNA synthesis produced a 338-bp PCR products using GPx specific PCR primer. Controls lacking reverse transcriptase resulted in the production of no detectable PCR products. RT-PCR using GPx PCR primers resulted in visible amplified products with adrenal gland mRNA (Table-I, Fig. 5)

A single band of predicted size (338bp) was obtained using specific primers for adrenal gland. RT-PCR result showed oxidation stress through specific primer GPx (specific for amplified gene for glutathione peroxidase enzyme. S-1 (100mg $\mathrm{NaF})$ and S-2 samples (200mg NaF) showed the band at approx. 338bp. And S-3 (300mg NaF) samples showed the band at specific 338bp (Fig. 6).

\section{RAPD (Random Amplification of Polymorphic DNA)}

The gene expression of glutathione proxidase was measured by RT-PCR using gene specific primer. The fluoride intoxication for 40 days resulted in reduced GPx activity of adrenal in group S-1 (exposure to $100 \mathrm{ppm}$ concentration), S-2 (exposure to $200 \mathrm{ppm}$ concentration) and $\mathrm{S}$ 3 (exposue to $300 \mathrm{ppm}$ concentration) of all experimental groups as compared to control (Figs. 7, 8, 9, 10).

\section{At first primer}

$\mathrm{S}-\mathrm{I}$ is more similar to control due to low dose of fluoride. S-2 and S-3 showed more variation due to high dose of fluoride.

\section{At second primer}

S-5 showed similarity with control.

\section{At third primer}

$\mathrm{S}-7$ is more similar to control due to low dose of fluoride. S-8 and S-9 showed more variation due to high dose.

\section{Total Proteins}

The level of proteins in adrenal gland of test rats showed significant $\quad(\mathrm{F}=9068.00$, $\mathrm{p}<0.001)$ decline after 40 days of fluoride toxicity (Fig.11). Most prominent decrease was registered in 200 and 300 ppm fluoride groups.

Bonferroni multiple comparison test after ANOVA $(\mathrm{F}=9068.00, \mathrm{p}<0.001)$ revealed significant decrease in the level of proteins in adrenal gland $(95 \% \mathrm{CI}=0.349$ to 0.765$)$ with mean difference of 0.419 to 0.695 among all fluoride treated groups as well as compared to control.

Pearson's bivariate correlation analysis revealed a significant $(\mathrm{r}=-0.925, \mathrm{p}<0.01)$ negative relationship between level of fluoride and levels of total proteins in adrenal gland of test rat after 40 days of fluoride treatment. Further regression analysis $\quad(\mathrm{Y}=7.213+4.99 \mathrm{X}-$ $\left.56.03 \mathrm{X} * 2+58.85 \mathrm{X} * * 3, \mathrm{R}^{2}=0.971\right)$ showed that as the level of fluoride increases in adrenal gland of rats, total proteins were declined (Fig. 12). 


\section{SDS PAGE analysis of proteins}

Polypeptide profile of total proteins of adrenal gland treated with different concentration of fluoride at 40 days was revealed by SDS-PAGE.

In adrenal gland of male rat, Lane-1 showed 14 dectable protein bands at $100 \mathrm{ppm}$ fluoride concentration. Lane-2, 11 bands at $300 \mathrm{ppm}$ concentration and Lane-3, 13 bands at $200 \mathrm{ppm}$ concentration as compared to control. In Lane-4 15 protein bands over a wide range of molecular weight (14.4 to $116 \mathrm{kda})$ were recognized (Fig. 13).

In female, adrenal gland revealed 10 clearly detectable protein bands in sample S-4 (100 ppm fluoride concentration), 8 protein bands in S-5(300 ppm concentration) as compared to control in which 14 protein bands.

Furthermore, the gradual decline in the quantity of polypeptide groups in the profiles of adrenal gland were observed with the increasing dose of fluoride.

Table.1 Primer Sequences for GPx

\begin{tabular}{|c|c|c|}
\hline Gene & primers & $\begin{array}{l}\text { Product } \\
\text { (bp) }\end{array}$ \\
\hline GPx & $\begin{array}{c}\text { '5'- } \\
\text { CTTGGATCCGAATTCATGACCCCCAG } \\
\text { GCTGGAAAAGAT-3' } \\
(\text { sense }) \\
\text { 5'- } \\
\text { CTGCAGGATCTTATATGGTTTTGAATT } \\
\text { GATT-3' } \\
\text { (antisense) }\end{array}$ & 338 \\
\hline
\end{tabular}

Primer 1: 5'-GATTCACTGC-3'

C-Control,

S-1- Sample on exposure to $100 \mathrm{ppm}$ concentration of fluoride.

S-2- Sample on exposure to $200 \mathrm{ppm}$ concentration of fluoride.

$\mathrm{S}$-3- Sample on exposure to $300 \mathrm{ppm}$ concentration of fluoride.

Primer 2: 5'-TGTCTGGGTG-3'

C2-Control,

S-4- Sample on exposure to $100 \mathrm{ppm}$ concentration of fluoride.

S-5- Sample on exposure to $200 \mathrm{ppm}$ concentration of fluoride.

S-6- Sample on exposure to $300 \mathrm{ppm}$ concentration of fluoride.

Primer 3: 5'-GGTCCCTGAC-3'

C3-Control

S-7- Sample on exposure to $100 \mathrm{ppm}$ concentration of fluoride.

S-8- Sample on exposure to $200 \mathrm{ppm}$ concentration of fluoride.

S-9- Sample on exposure to $300 \mathrm{ppm}$ concentration of fluoride. 
Fig.1 Changes in the level of DNA in adrenal gland of experimental rats

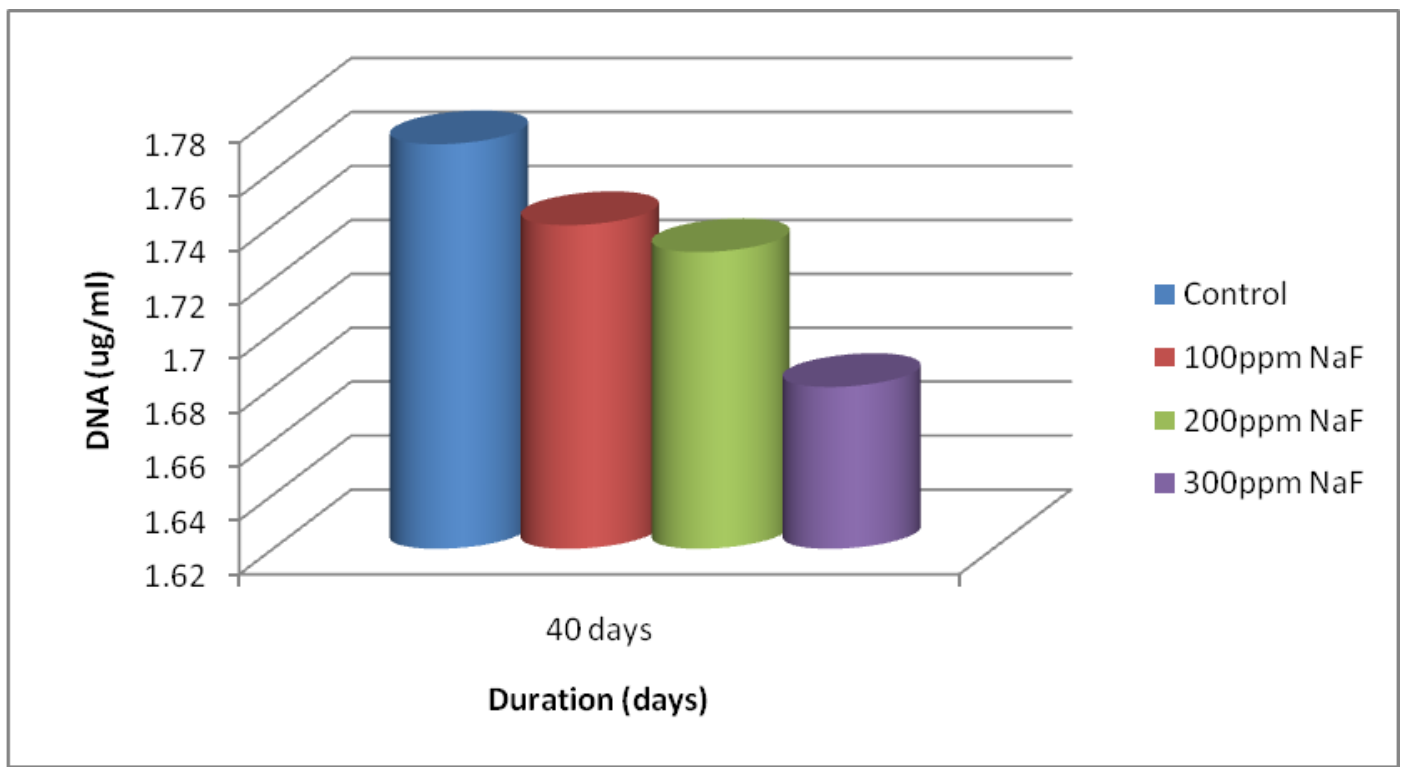

Fig.2 Scatter plot showing correlation between fluoride and level of DNA in test rats after 40 days of fluoride treatment

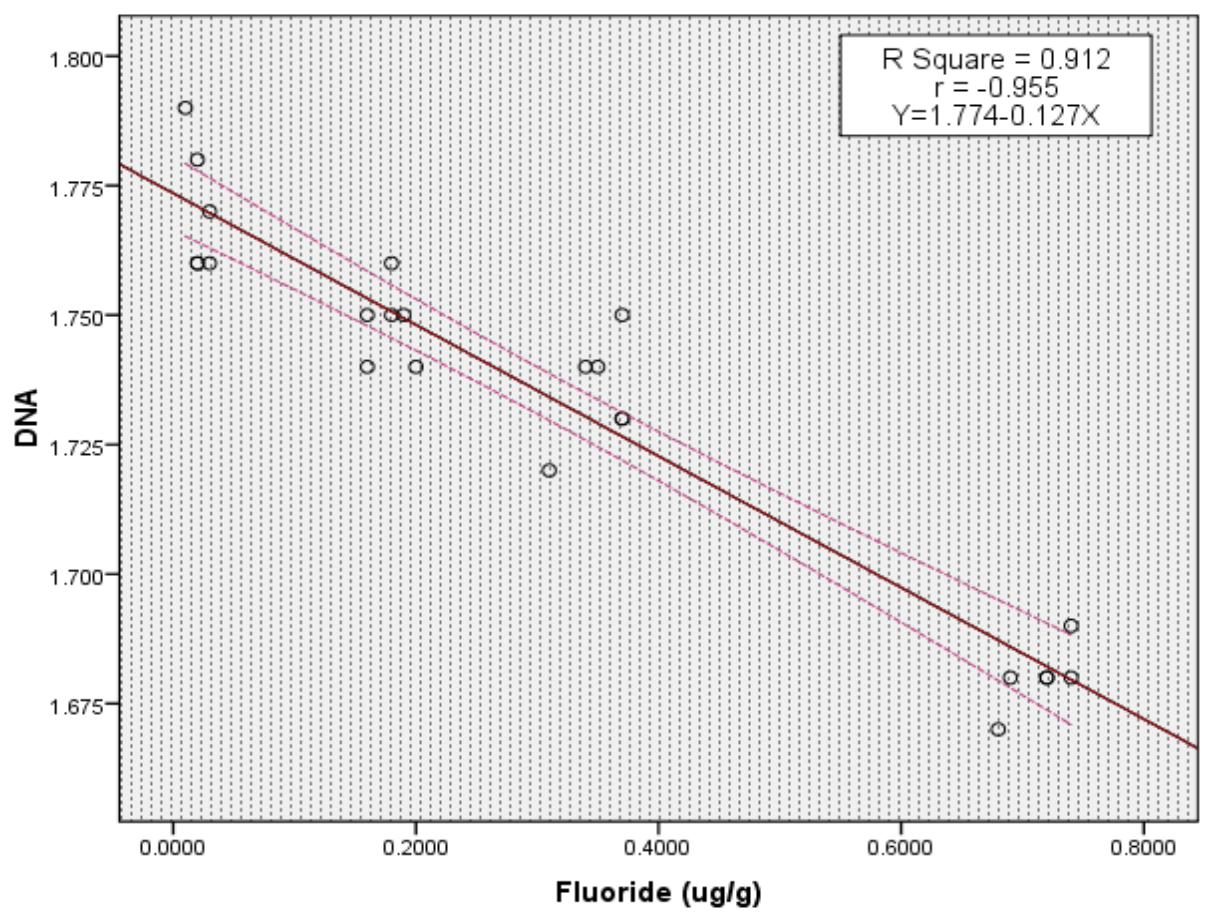


Fig.3 Changes in the level of RNA in adrenal gland of experimental rats.

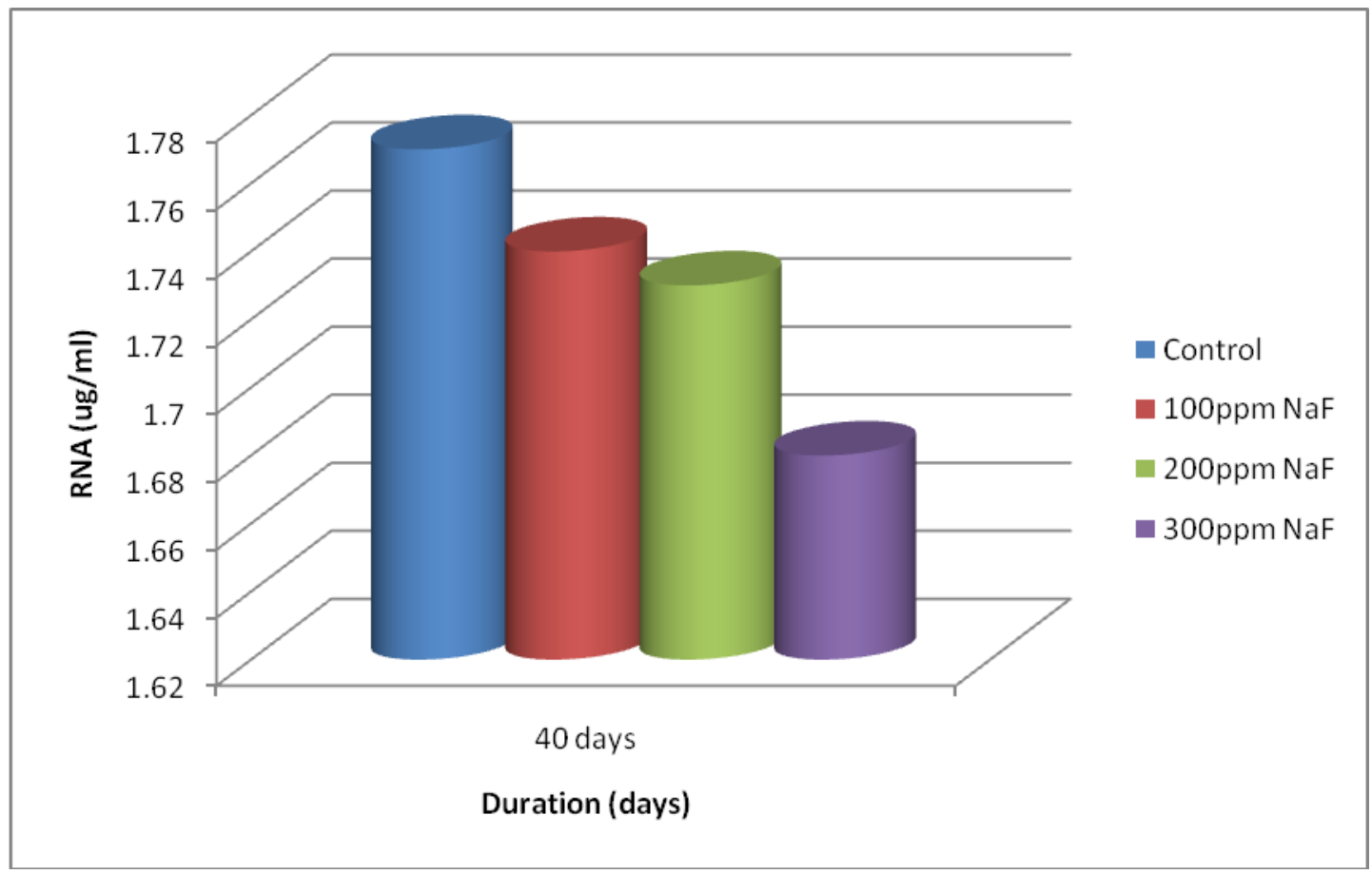

Fig.4 Scatter plot showing correlation between fluoride and level of RNA in test rats after 40 days of fluoride treatment.

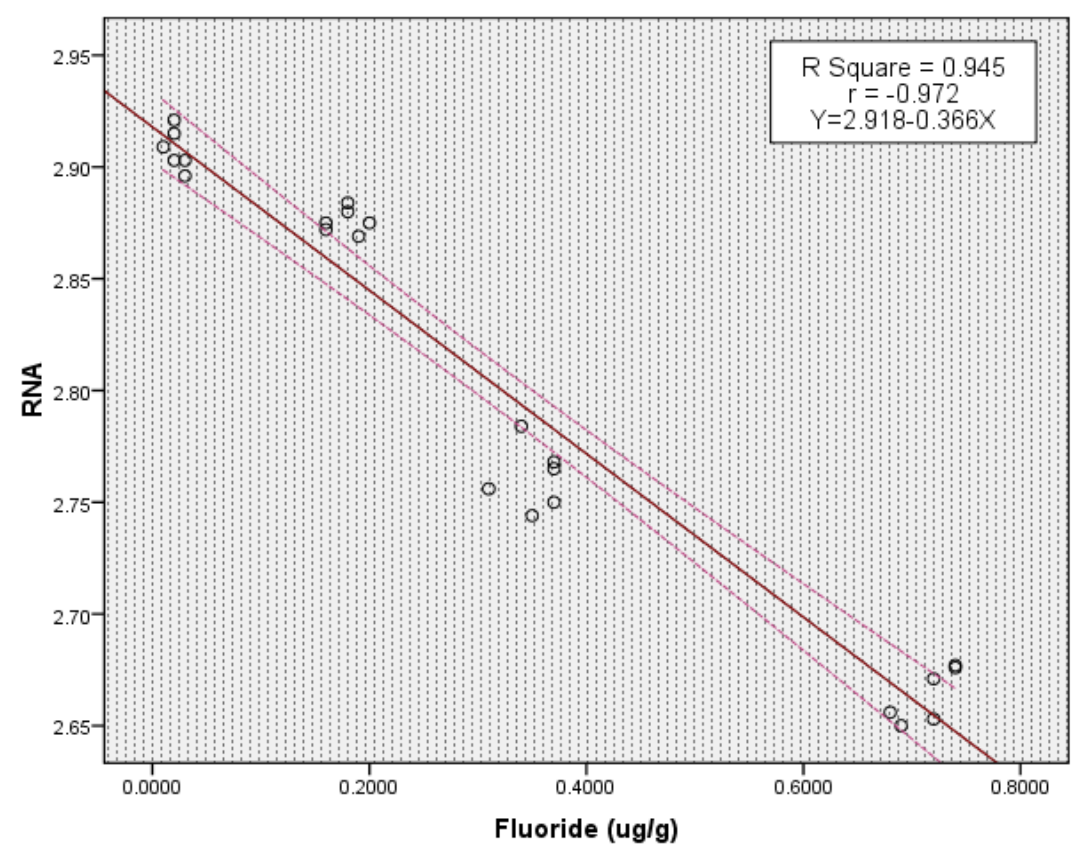


Fig.5 Agarose gel electrophoresis of total mRNA extracted from adrenal gland.

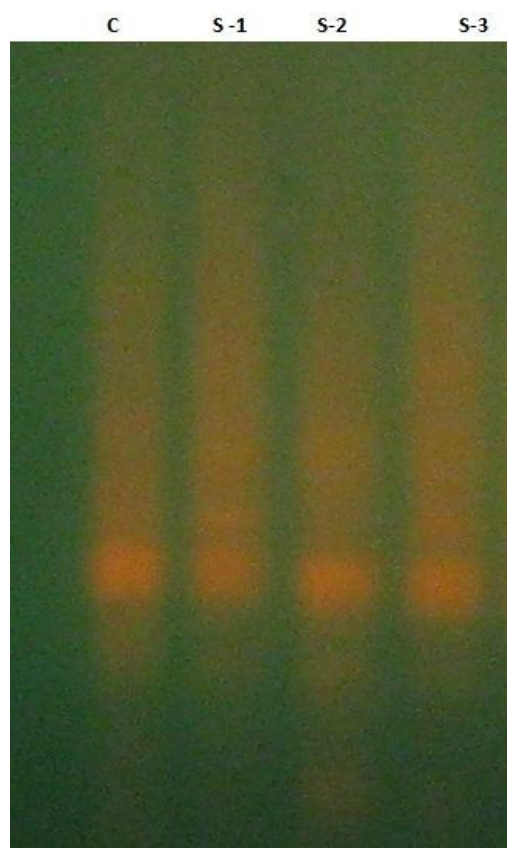

C- Control

S-1-Tissue sample on exposure to 100ppm concentration of fluoride S-2-Tissue sample on exposure to 200ppm concentration of fluoride S-3-Tissue sample on exposure to 300ppm concentration of fluoride

Fig.6 Agarose gel electrophoresis RT-PCR products from total RNA isolated using Trizol. The gel were stained with ethidium bromide and photographed using Polaroid camera. LaneM:100bp DNA Ladder.

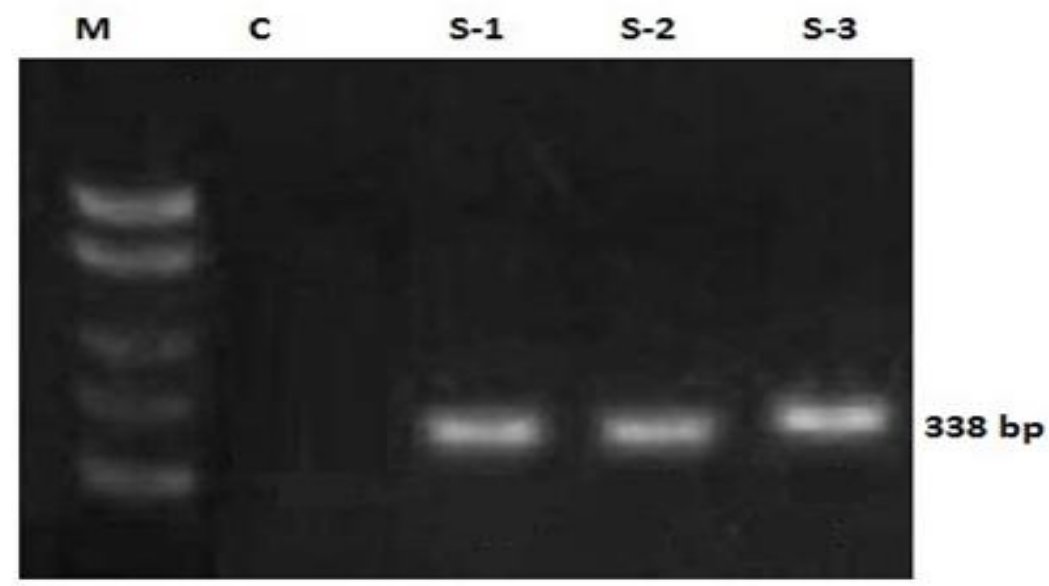

Lane C-Control

LaneS-1: Glutathione peroxidase (on exposure to 100ppm concentration of fluoride. LaneS-2: Glutathione peroxidase (on exposure to 200ppm concentration of fluoride. LaneS-3: Glutathione peroxides (on exposure to 300ppm concentration of fluoride 
Fig.7 RAPD gel image for fluoride treated adrenal tissue of rat at various concentrations.

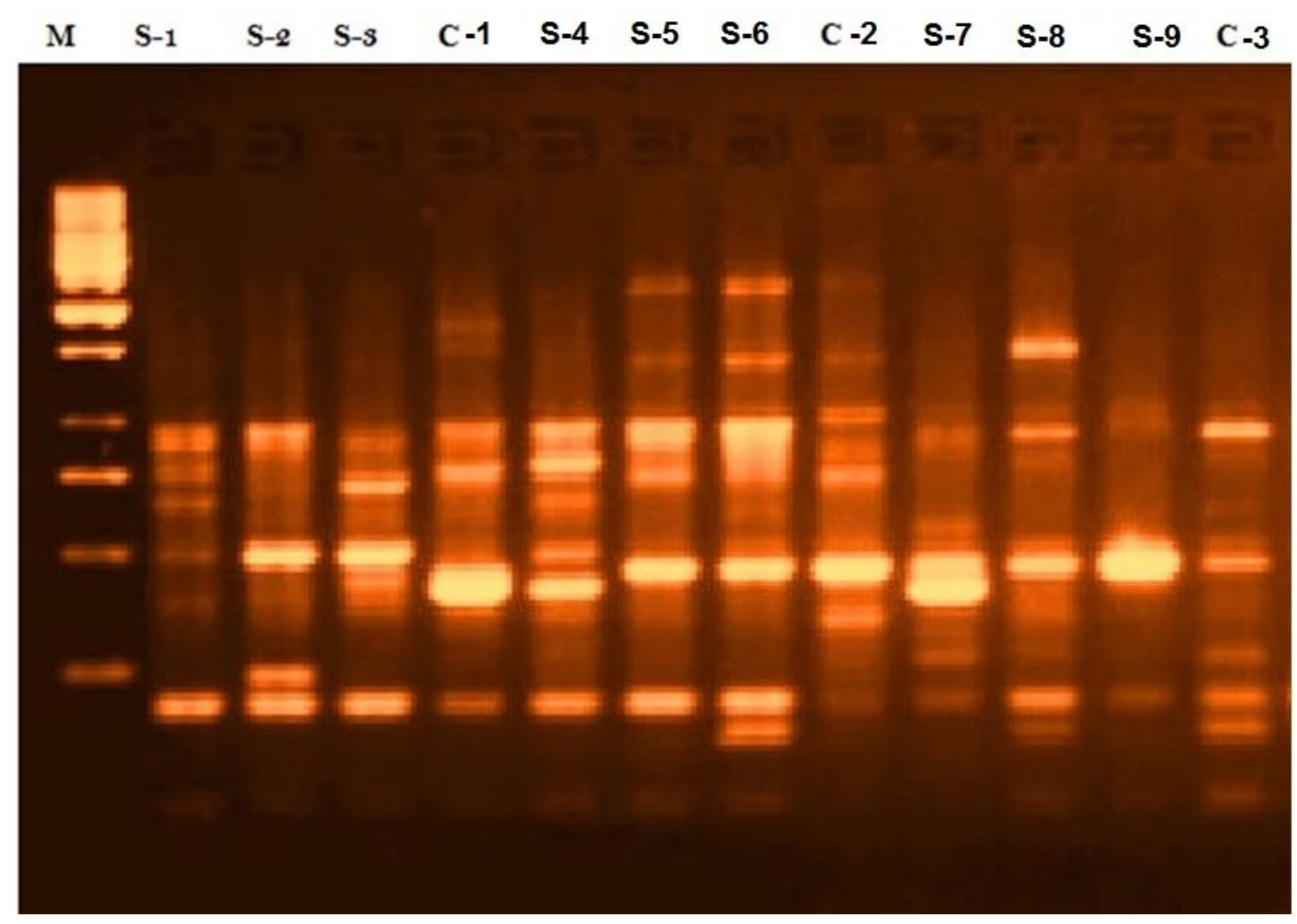

Fig.8 9,10
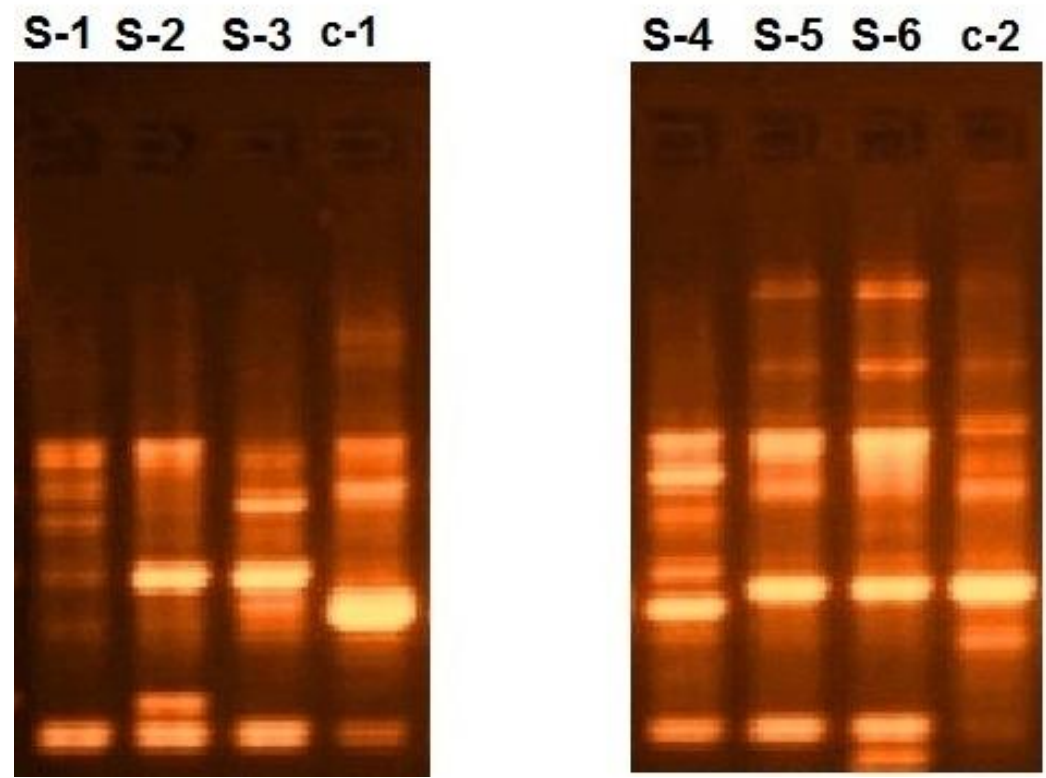

S-7 S-8 S-9 c-3

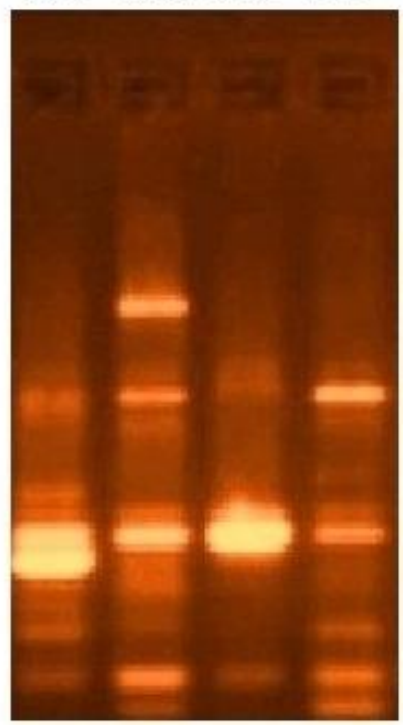


Fig.11 Changes in the level of total proteins in adrenal gland of experimental rats.

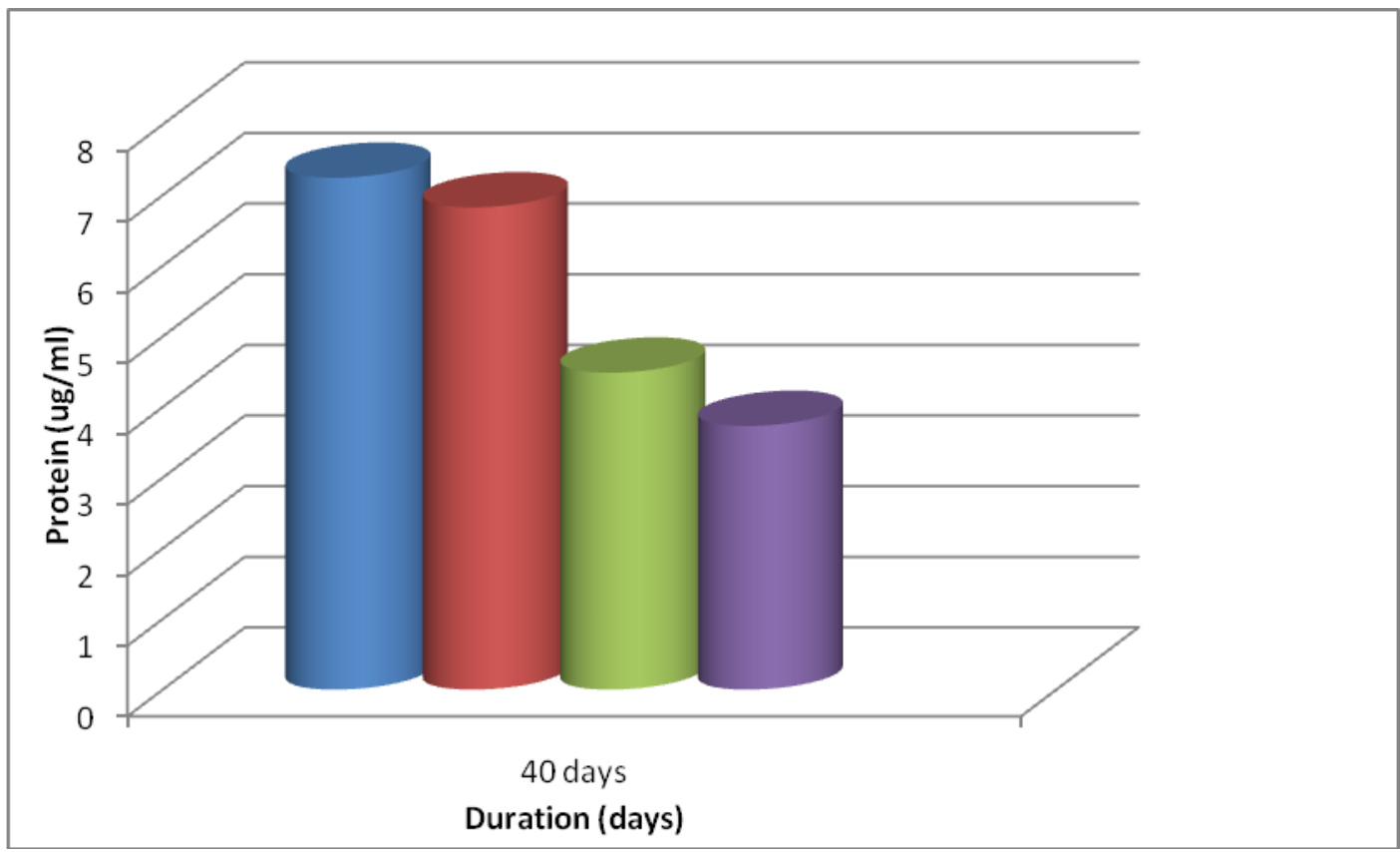

Fig.12 Scatterplot showing correlation between fluoride and level of proteins in test rats after 40 days of fluoride treatment.

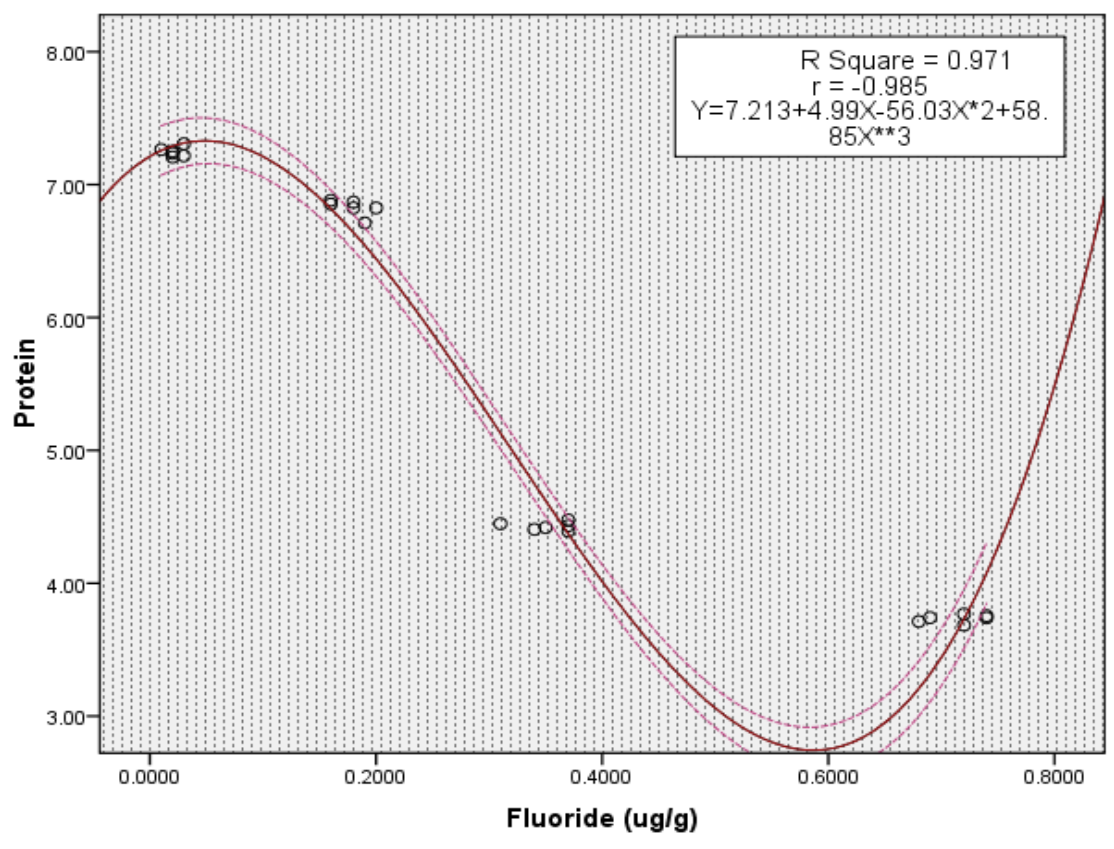


Fig.13 SDS- PAGE Polypeptide profiles of total protein in adrenal of rat under control and on exposure to different concentration of fluoride (100 ppm, $200 \mathrm{ppm}$ and $300 \mathrm{ppm})$ at 40 days.

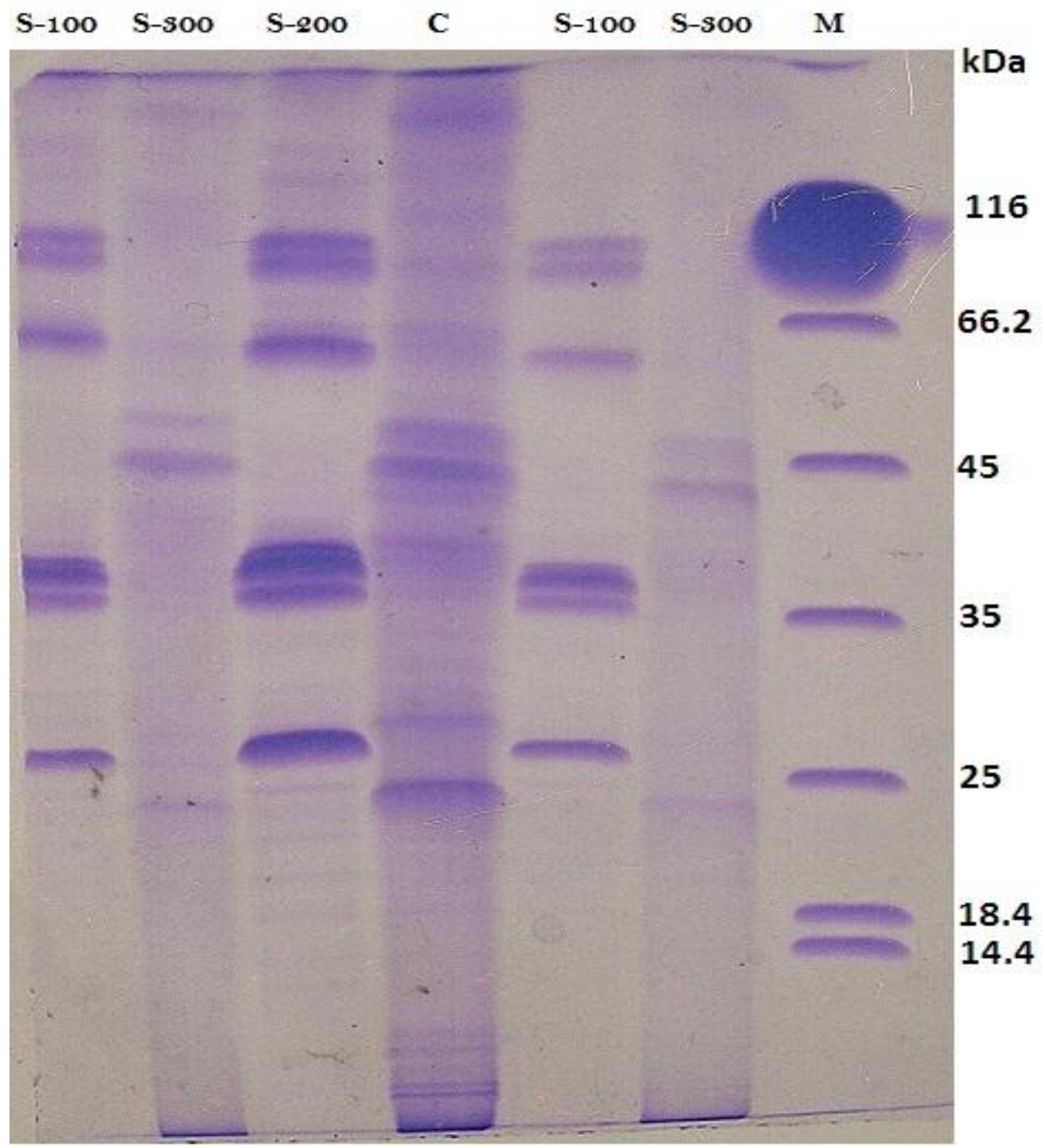


Fig.14 Western Blotting in the adrenal gland of rats on exposure to different concentration of fluoride (100 ppm, $200 \mathrm{ppm}$ and $300 \mathrm{ppm}$ ) at 40 days.

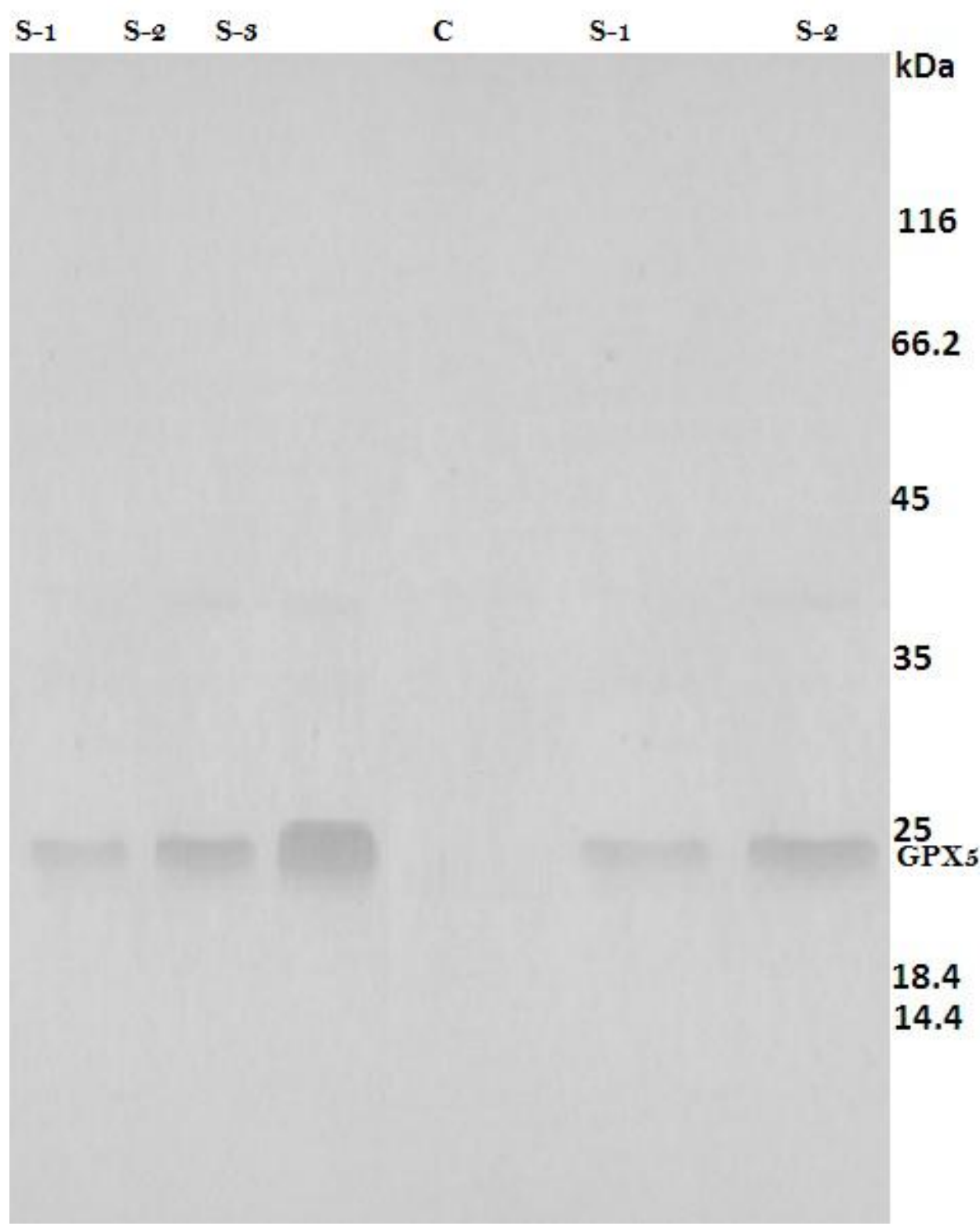

\section{Western blotting of proteins}

Due to oxidative stress, protein was expressed at $24-\mathrm{kDa}$ in all the samples treated with fluoride as compared to control. The inhibition of glutathione peroxidase by oxidative stress has been identified as a key factor in the regulation of growth factor receptors by environmental stress (Fig.14).
Protein expression of enzymes produced during oxidative stress increased in rats that were given 100 ppm, 200 ppm and 300 ppm fluoride/kg/b.w. respectively. Fluoride treatment decreased the total protein contents in the adrenal gland of all experimental rats. It suggested the suppression of protein synthesis and utilization of protein for energy purposes. 
This could be attributed to ability of fluoride to modify the ratio of free nucleotide and that of RNA, to decrease the rate of RNA synthesis and to enhance ribonuclease activity. At the subcellular level, nuclear DNA is either decreased or either remains unchanged, but a decrease was reported in intracellular mRNA which was consistent with previous investigations (Baudene, 1975; Chang, 1978; Holland, 1978).

The elevated mRNA levels and correspondingly high enzyme activity of GPx in the adrenal gland during present study indicates post-translational effect of oxidative stress in adrenal gland. An increase in GPx mRNA in the presence of higher concentration of $\mathrm{H}_{2} \mathrm{O}_{2}$ has been reported (Shull et al., 1991).

GPx has reduced lipid peroxides. GPx plays a role in cellular defence against ROS. In the present study, the GPx activity increased. Which suggest that there could be compensatory mechanism between the antioxidant enzymes in response to oxidative stress. GPx enzymes cope with oxidative stress and it is shown in PCR result.

The high activity of GPx indicates posttranslational effects of oxidative damage in adrenal gland. The GPx activity in kidney has also been found to increase in the most studies. The decrease in GPx activity despite unaltered mRNA level could be due to inactivation by $\mathrm{O}_{2}^{-}$anion (Blum and Fridovich, 1985) post-translational modification such as non- enzymatic glycation of the enzyme protein (Baldwin et al., 1995). Oxidative stress, DNA damage and modification of membrane lipids can be induced in hepatocyte by excess fluoride (Wang et al., 2004; He and Chen, 2006; Clarke et al., 2008).
With high dose concentration of fluoride, rapid gel images showed greater variation then at low dose. Probably, because high fluoride concentration bring about certain mutation which change the primer binding site, due to which there were variations in the rapid gel images from the control.

Random amplified polymorphic DNA marker were generated via the polymerase chain reaction using short primers of an arbitrary sequence and a lower annealing temperature then standard PCR reaction (Williams et al., 1990). The total protein content declined progressively in adrenal gland and was registered in all samples on exposure to fluoride. The decrease protein content can be explained by decrease in protein synthesis and enhanced protein degradation. Earlier studies from our laboratory revealed a dose-dependent decline in protein level in brain (Shashi et al., 1994) in experimental fluorosis in rabbit.

The data obtained in the present study show clearly that intake of water containing 100 , 200 and 300 ppm sodium fluoride for 40 days resulted in a marked decrease in the level of DNA, RNA and protein in the adrenal gland of rat, which was consistent with previous investigation (Shashi et al., 1994; Shashi, 2003).

The significance declined of DNA and RNA in adrenal gland of fluoride rabbit in this investigation may be due to alteration in DNA polymerase activity and change in enzymes involved in nucleic acid synthesis (Shashi, 2003).

Jacinto-Aleman et al., (2010) suggested that excessive fluoride ingestion has been identified as a risk factor for fluorosis and oxidative stress. 


\section{Conflicts of interest statement}

Author declares that there is no conflict of interest.

\section{References}

Baldwin, J.S., Lee, L., Leung, T.K., Muruganandam, A. and Mutus, B. 1995. Identification of the site of nonenzymatic glycation of glutathione peroxidase : rationalization of the glycation-related catalytic alteration on the basis of three-dimensional protein structure. Biochem. Biophys. Acta., 1247(1): 60-64.

Barbier, O., Mendoza, L.A., Razo, L.M.D. 2010. Molecular mechanisms of fluoride toxicity. Chem-bio. Interact., 188: 319-333.

Baudene, C., 1975. Fluor et enzymes. Med. Natr., 9:75-78.

Berger, M.S., Locher, G.W., Saurer, S., Gallick. W.X., Watufied, M.D., Groner, B. and Hynes, N.E. 1988. Correlation of c-erb $\beta 2$ gene amplification and protein expression in human breast carcinoma with nodal status and nuclear grading. Cancer Res., 48: 1238-1243.

Blum, J. and Fridorich, I. 1985. Inactivation of glutathione peroxidase by superoxidase radical. Arch. Biochem. Biophys., 247: 1-11.

Botstein, D., White, K.L., Skolnick, M. and Davis, R.W. 1980. Construction of a genetic linkage map in man using restriction fragment length polymorphism. Am. J. Hum. Genet., 32: 314-331.

Chang, C.W., 1978. Comparison of the biochemical mechanism of growth retardation caused by fluoride and ozone. Fluoride, 11: 55-59.

Chomczynski, P. and Mackey, K. 1995. Short technical reports. Modification of the TRI Reagent procedure for isolation of RNA from polysaccharide and proteoglycan rich sources. Biotechniques, 19: 942-945.

Clarke, S.J., Das, I.K.M., Parker, J.E., Heesom, K.J. and Halestrap, A.P. 2008. Inhibition of mitochondrial permeability transition pore opening by ischemic preconditioning is probably mediated by reduction of oxidative stress rather than mitochondrial protein phosphorylation. Circulation Res., 102: 1082-1090.

Frohman, M.A., Dush, M.K. and Martin, G.R. 1988. Rapid production of fulllength cDNAs from rare transcripts: Amplification using a single genespecific oligonucleotide primer. Proc. Nati. Acad. Sci., 85: 8998-9002.

He, L.F., and Chen, J.G. 2006. DNA damage apoptosis and cell cycle changes induced by fluoride in rat oral mucosal cells and hepatocyte. World $J$. Gastroenteroi., 12(7): 1144-1148.

Hinson, J.P., Raven, P.W. 2006. Effect of endocrine-distrupting chemical on adrenal function. Best Pract. Res. Clin. Endocrinol. Metab., 20(1):111-120.

Hoarau, G., Coyer, J.A., Stam, W.T. and Olsen, J.L. 2007. A fats and inexpensive DNA extraction/ purification protocol forbrown macroalgae. Mol. Ecol. Notes, 7: 191193.

Holland, R.I. 1978. Fluoride inhibition of protein and DNA synthesis in cells in vitro. Acta Pharmacol. Toxicol., 45: 96-101.

Jacinto-Aleman, L.F.I., HernandezGuerrero, J.C., Trejo-Solis, C., Jimenez-Farfan, M.D. and Fernandez

Presas, A.M. 2010. In vitro effect of sodium fluoride on antioxidative enzymes and apoptosis during murine odontogenesis. J. Oral. Pathol. Med., 
39(9): 709-714.

Lowry, O.H., Rosenbrough, N.J., Farr, A.L and Randall, R.J. 1951. Protein measurement with folin Phenol reagent. J. Biochem., 193: 265-275.

Poinar, J.R.G.O and Jnasson, H.B. 1986. Infection of Neoaplectana and Heterorhabditis (Rhabdita: Nematoda) with the predatory fungi, Monacrosporium ellipsosporum and A rthrobotrys oligospora (Moniliales : Deuteromycetes). Revue Nematol., 9: 241-244.

Shashi, A. 2003. Fluoride and adrenal gland function in rabbits. Fluoride, 36(4): 241-251.

Shashi, A., Singh, J.P. and Thapar, S.P. 1994. Effect of long-term administration of fluorideon levels of protein, free amino acids and RNA in rabbit brain. Fluoride, 27:155-9.

Shull, S., Heintz, N.H., Periasamy, M., Manohar, M., Janssen, Y.M., Marsh, J.P. and Mossman, B.T. 1991. Differential regulation of antioxidant enzymes in response to oxidants. $J$. Biol. Chem., 266: 24398-24403.

Strong, D.R., Lawton, J.H. and Southwood, R. 1984. Absolute quantification of mRNA using real time reverse transcription polymerase chain reaction assays. J. Mol. Endocrinol., 25: 169-193.

Verma, Y., Rana, V.S. 2009. Endocrinology toxicity of industrial solvents - A mini review. Indian J. Exp. Biol., 47:537549.

Wang, A., Xia, T., R. R., Yuan, J., Chen, X., Wuhan, K.Y. 2004. Antagonistic effect of selenium on oxidative stress, DNA damage and apoptosis induced by fluoride in human hapatocytes. Fluoride, 37(2): 107-116.

Williams, J.K.G., Kubelik, A.R.K., Livak, J.L., Rafalski, J.A. and Tingey, S.V. 1990. DNA polymorphism -amplified by random primers are usefull as genetic marker. Nucleic Acids Res., 18: 7213-7218.

\section{How to cite this article:}

Shashi, A., and Neha Sharma. 2016. Molecular Changes and Gene Expression of Glutathione Peroxidase in Adrenal Gland during Experimental Fluorosis. Int.J.Curr.Microbiol.App.Sci. 5(12): 437-451. doi: http://dx.doi.org/10.20546/ijcmas.2016.512.048 